\title{
Integrating Business Process Improvement and Information Systems to Improve Service Quality: A Conceptual Model
}

\author{
Pipin Anggaliya and Endang Chumaidiyah \\ Department of Industrial Engineering, Telkom University, Bandung \\ e-mail: pipinanggaliya@gmail.com, endangcn@gmail.com
}

\begin{abstract}
Abstrak-PT. $\mathrm{X}$ is a company that is engaged in testing telecommunications equipment. In its business activities there are some special problems in the current business processes and information systems that are not optimal. This research was conducted to examine the quality of services produced by business processes and information systems used today. The method used is to integrate Business Process Improvement with information systems to improve service quality. The results obtained from this study consist of a conceptual model for getting business processes and designing information systems that have accommodated business process and service improvements.
\end{abstract}

Keywords-Business process improvement, information system, e-servqual and importance performance analysis.

\section{INTRODUCTION}

$\mathrm{T}$ ECHNOLOGICAL development has increased significantly. One of the developments in question is the information technology and telecommunications.

In 2019 growth in sales and use of electronics products in Indonesia will increase by $24 \%$ [1]. Of the many telecommunications equipments circulating in the community and industrial companies, not all of them have fulfilled telecommunications standards applied in Indonesia. For this reason, standardization of equipment testing is very important to ensure that telecommunications devices circulating in the community and companies are certified or have passed due diligence. The electronic or telecommunications products that dominate the Indonesian market are foreign products such as China and Japan [2]. Company $\mathrm{X}$ has a business unit engaged in device testing. Previous studies measured service quality at the testing center to get a picture related to the quality of services provided using the servqual method, Importance Performance Analysis (IPA), Internal Success Method (MSI), Customer Satisfaction Index (CSI). After analyzing company $\mathrm{x}$ in its business activities there are some problems mainly in business processes and information systems that are not optimal. As for the problems that occur in company $\mathrm{X}$ namely the testers do not get a notification or reminder on the system related to the request for a function test, the admin has difficulty getting information related to device research from testers such as test progress and test reports, the admin verifies the registration of customers by downloading the file requirements one by one not multifile. Then there are complaints submitted by customers namely about the length of device research, difficulties in registering the company, lack information related to the progress of testing and notifications that are less informative and do not know the number of the ongoing test queue. This research was conducted to examine the quality of services caused by business processes and information systems used today. The purpose of this study is to examine more deeply the problems in business systems and processes to improve the quality of service testing equipment by measuring service quality, business process improvement and importance performance analysis.

\section{METHODOLOGY}

Business process improvement (BPI) is a method developed to assist companies or organizations in improving the performance of existing business processes. BPI is also used to redesign business processes that are running to improve performance significantly [4]. The objective of Business Process Improvement (BPI) consists of 3 objects namely; Effectiveness, Efficiency and Adaptability. EServqual is the development of servqual to manage the business in the segmentation of customers who interact by using electronic media, in implementing e-servqual can bring benefits to customers and business people [4]. There are 6 dimensions of E-servqual, as follows [5]; information quality, security, website structurality, customer relationship, responsiveness and fulfillment. Importance performance analysis is an analysis technique used to identify important performance factors that must be demonstrated by organizations in meeting the satisfaction of their service users. Initially, science was used for research in the field of marketing. However, its use is widespread in various service areas such as school health and government. IPA is used to understand users' deeper perceptions about the quality of services provided [6].Conclusions from the results of the matrix; Quadrant I Concentrate Here attributes in this field attribute with high priority to be the focus of improvement; Quadrant II Keep Up The Good Work attribute in this field is an attribute that has been successfully applied to the company. Already in line with expectations and maintained; Quadrant III Low Priority is an attribute that is considered less important and unsatisfactory; Quadrant Possible Overkill is an attribute that is too excessive and is considered less important by the user so it must be managed again so as not to consume too many resources. 
2nd International Conference on Industrial and System Engineering (IConISE) and

7 th Annual Conference on Industrial and System Engineering (ACISE) 2020

July $22^{\text {nd }}-23^{\text {rd }} 2020$, Surabaya, Indonesia

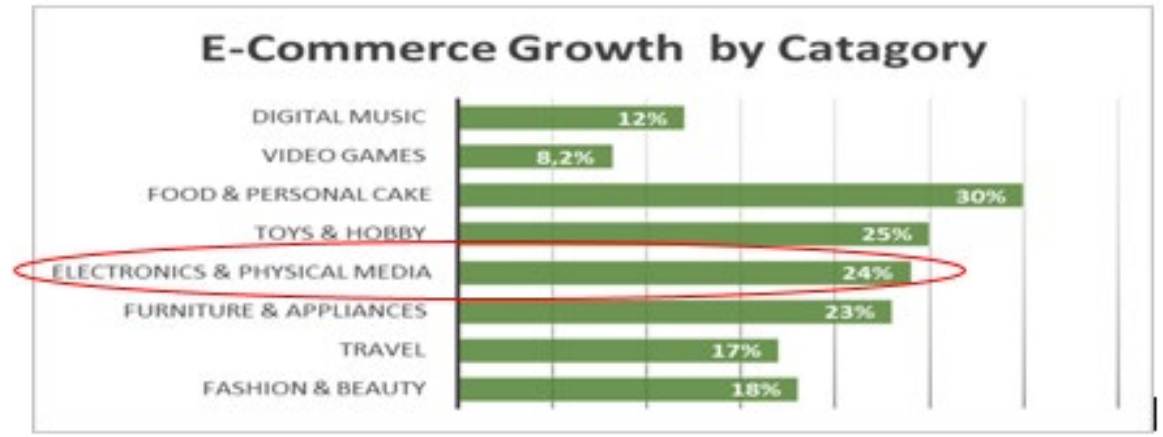

Figure 1. E-commerce growth by category.

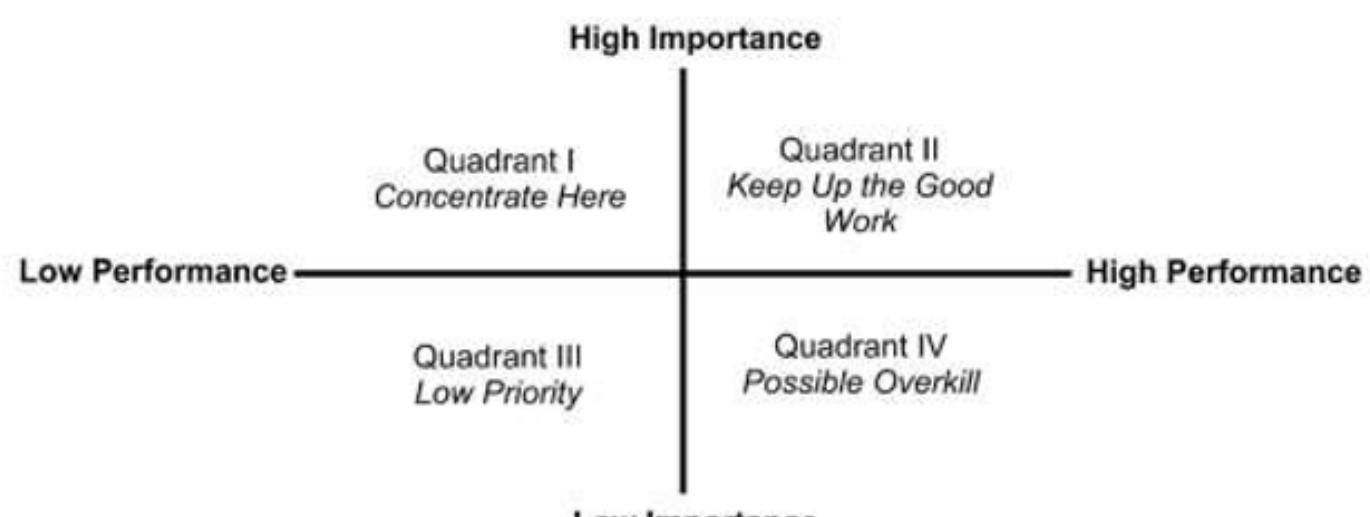

Low Importance

Figure 2. Matrix importance performance analysis.

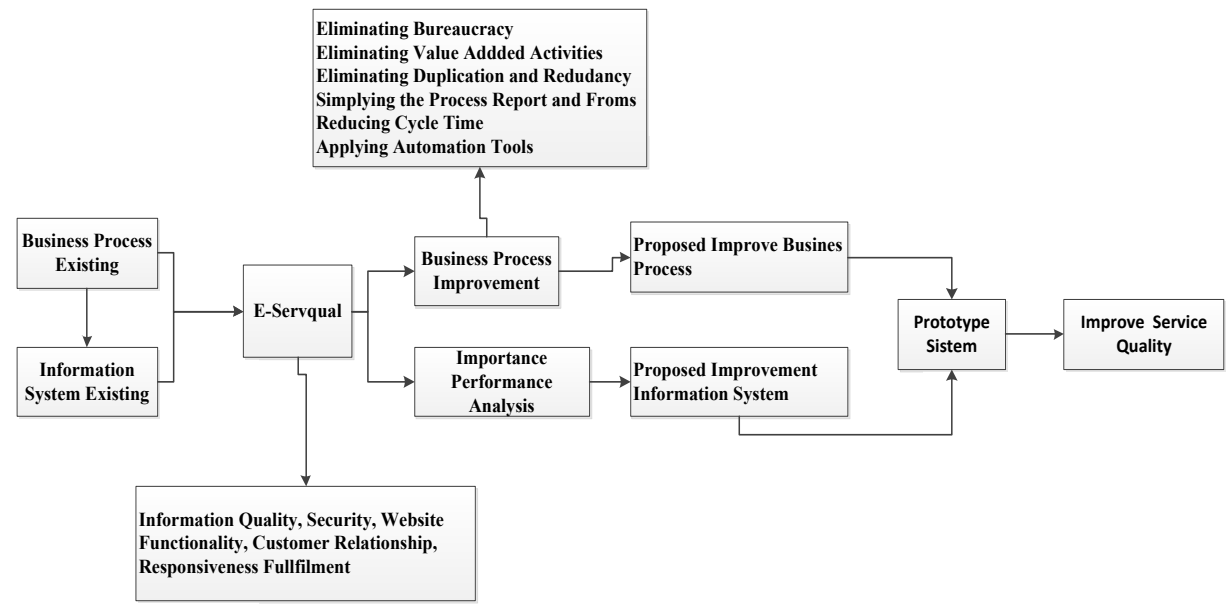

Figure 3. Proposed conceptual model for improve service quality.

This study uses the Business Process Improvement method with the Apply Improvement Technique approach to improving company performance. Then the E-servqual method and Importance Performance Analysis to identify the factors that become a reference to meet customer satisfaction. The process of collecting data by conducting surveys and distributing questionnaires, the sample used was $25 \%$ or 30 respondents from 122 populations. In finding the correlation value the researchers used the Pearson product moment formula, namely:

$$
\frac{n\left(\sum X Y\right)-\left(\sum X\right)\left(\sum Y\right)}{\sqrt{\left.\left[n\left(\sum X^{2}\right)-\left(\sum X\right)^{2}\right]\left[\sum Y^{2}\right)-\left(\sum Y\right)^{2}\right]}}
$$

Explanation ; $\begin{array}{ll}\mathrm{r} & \text {; Correlation coefficient } \\ \mathrm{n} & \text {; Number of respondents } \\ \sum X & \text {; Total Score of instrument items } \\ \sum Y & \text {; Total number of answer scores } \\ \sum X^{2} & \text {; Sum of the squares of the item's score } \\ \sum Y^{2} & \text {; Sum of the squares of the answer score } \\ \sum X Y & \text {; Number of times the score of an item's answer }\end{array}$ by the total score

\section{RESULT}

The results of problem identification and literature review from several previous research journals on service quality and business process improvement produce a conceptual model. The conceptual model is a framework explaining 
2nd International Conference on Industrial and System Engineering (IConISE) and

7th Annual Conference on Industrial and System Engineering (ACISE) 2020

July $22^{\text {nd }}-23^{\text {rd }} 2020$, Surabaya, Indonesia

ideas that will be a reference in overcoming problems. As has been modeled in Figure 3 which is the result of problem identification, the figure below shows efforts in improving the quality of customer service regarding device testing, as for the following research;

1. Business process Existing; At this stage, the researcher identified the current business processes to find out the problems that exist in the testing of telecommunications equipment.

2. information system Existing; After identifying the existing business processes, the researcher identified the problems in the current information system to find out the problems felt by the customer for the system provided for device testing.

3. E-servqual; This stage is the data processing stage, where the data obtained from the results of the distribution of questionnaires regarding system performance and business processes using e-servqual methods consisting of 6 dimensions, then the results of Information Quality, Security, Website Functionality, Customer Relationship, Responsiveness and Fulfillment.

4. Business process improvement; This stage is an advanced stage of e-servqual research, where the results of e-servqual will be integrated with the business process improvement method by using the Apply Improvement Technique approach to improve company performance.

5. Proposed improvement business process; Is the result of the integration of e-servqual and business process improvement, namely the proposed business process improvement.

6. Importance Performance Analysis; at this stage the results of e-servqual will be integrated with the importance performance analysis method to illustrate the priority factors that will be a reference in the development of information systems.

7. Proposed improvement Importance Performance Analysis; is the result of the integration of e-servqual and Importance Performance Analysis, namely the proposed improvement of information systems.

8. Prototype system; the next stage is intensifying business processes and information systems where the results of the integration are prototype systems where this proposal will improve the existing system to improve the quality of service on device testing. The following is a proposed conceptual model.

\section{DISCUSSION}

After analyzing company $\mathrm{x}$ in its business activities there are some problems mainly in business processes and information systems that are not optimal. This research was conducted to examine more deeply about problems in business systems and processes to improve the quality of service testing equipment by measuring service quality. In this study using the e-servqual method, business process improvement and importance performance analysis are used for research in marketing. The results of this study are proposed improvements to information systems and business processes in the form of a prototype system.

\section{REFERENCES}

[1]. Page, Susan 2015 The Power of Busniness Process Improvement. (2nd Edition ). New York: American Management Association.

[2]. Martilla JA, James JC 1977 Importance-Performance Analysis. J Mark. SAGE $\quad$ Publications $41(1): 77-9$ doi.org/10.1177/002224297704100112

[3]. Ho C-I, Lee Y-L 2007 he development of an e-travel service quality scale. Tour Manag. Elsevier BV 28(6):1434-49. doi.org/10.1016/j.tourman.2006.12.002

[4]. Kominfo 2018 "Data Pengujian Perangkat SDPPI": kominfo.go.id November 20, 2019.

[5]. Lupiyoadi, Rambat 2014 Manajemen Pemasaran Jasa Berbasis Kompetensi. Edisi ke-3. Jakarta: Salemba Empat.

[6]. Page, Susan 2015 The Power of Busniness Process Improvement. (2nd Edition ). New York: American Management Association. 